\title{
USING SERVICESCAPE TO MANAGE STUDENT COMMITMENT TOWARDS A HIGHER EDUCATION INSTITUTION
}

\author{
E. Theron* \\ e-mail: et3@sun.ac.za
}

\author{
A. Pelser* \\ e-mail: almeri.pelser@gmail.com \\ *Department of Business Management \\ University of Stellenbosch \\ Stellenbosch, South Africa
}

\section{ABSTRACT}

Although a variety of approaches can be used to manage student commitment, the role of physical elements, such as a facility or institution's virtual presence, appearance of infrastructure and signage, is often neglected in the literature. This gap in the literature is surprising considering the growing interest in the field of social sciences regarding the influence of physical elements (or tangibles) on commitment. It is against this background that this study investigated the possible effects of physical element attributes on student commitment. A number of antecedents of physical elements were identified by means of a literature review and their expected relationships with student commitment were proposed as hypotheses. These hypothesised relationships were assessed and a survey amongst 290 students from a multi-cultural South African university was conducted. The statistical program SPSS version 23 was used to analyse the data, and the hypothesised relationships were assessed by means of regression analyses. The findings of the study indicate that the physical element dimensions 'communicators' and 'virtual servicescape' most significantly influenced overall student commitment. Contrary to popular belief, the study revealed that social servicescape did not have a significant impact on student commitment. Furthermore, it appears that a specific set of physical element attributes should be applied when student commitment is managed. Finally, the study offers an in-depth discussion of the theoretical and managerial implications of these findings for relationship marketing strategies.

Keywords: student commitment, physical environment, higher education institutions

\section{INTRODUCTION AND BACKGROUND}

The South African higher education (HE) landscape has changed considerably since the country's first democratic election in 1994. A number of factors, such as the demand for free higher education and high dropout rates (38\% for residential universities and about 60\% for non-residential universities) (Subotzky 2015), have necessitated HE institutions to rethink their 
existing service offerings. Furthermore, the emergence of private universities, many of them affiliated with renowned global HE institutions, has resulted in increased competition among these institutions to attract the best prospective students. It should be noted that the HE environment in South Africa is characterised by further challenges such as poverty, unemployment, non-access to the different levels of education in general and a lack of facilities. However, it is crucial for HE institutions to withstand the almost unstoppable tide of concerns, and to retain their levels of academic excellence, and to contribute to student success rates.

Much has been written about the ways in which student success can be encouraged, and to make students committed to both their personal studies and their selected HE institutions, appear to be central in the literature. For example, previous research on student commitment has indicated the importance of instructor commitment (Dachner and Saxton 2015), financial aid (Strauss and Volkwein 2004) and academic integration (Beck and Milligan 2014). However, there still are other areas of student commitment that are under-researched. For example, as far as could be ascertained, no study could be found in which the influence of a student's physical environment (such as an institution's virtual presence, appearance of infrastructure and signage) on student commitment has been comprehensively investigated. However, these elements have been studied extensively from a social sciences perspective, where it has been established that a physical environment does play a significant role in an individual's commitment towards an organisation, service provider, product or brand (Mari and Poggesi 2013; Bitner 1992). The question is, therefore, whether a multidisciplinary approach could be used to apply the existing knowledge on the role of physical elements to student commitment. It is against this background that this study investigated the influence of a student's physical environment on their commitment to the HE institution of their choice.

\section{STUDENT COMMITMENT}

The importance of commitment has long been recognised as a key ingredient of any successful relationship (Morgan and Hunt 1994), whether it is commitment to personal relationships, such as marriage (Kelmer, Rhoades, Stanley and Markman 2013), or towards sports teams (Biscaia, Correia, Rosado, Ross and Maroco 2013), or towards non-profit organisations (Vecina, Chacón, Marzana and Marta 2013), to mention but a few.

Despite the different perspectives on commitment, researchers are almost unanimous in their findings that commitment is a powerful predictor of retention as well as intentions such as switching or staying with a firm or service provider (Jones, Fox, Taylor and Fabrigar 2010). Commitment can be defined as 'a force that binds an individual to a course of action of 
relevance to one or more targets' (Meyer and Herscovitch 2001, 299). This definition further holds that the underlying psychological states of commitment have the potential to influence an individual's behaviour and decision to maintain a relationship.

More recent research on commitment suggests that the concept should be viewed from a multi-dimensional perspective consisting of three distinct components: affective commitment, continuance commitment and normative commitment (Meyer and Allen 1997). Affective commitment originates from customers experiencing a psychological state of emotional attachment to a service provider (Fullerton 2003). The premise for this attachment are circumstances with which customers are able to identify with, participate in and feel delighted to be with a particular service provider (Gruen, Summers and Acito 2000). This type of commitment, therefore, refers to feelings of belonging, identification, shared values, dedication and resemblance (Pritchard, Havitz and Howard 1999).

Secondly, continuance commitment denotes the psychological binding force between a customer and a service provider based on the anticipated switching costs (Jones et al. 2010; Gilliland and Bello 2002). Switching costs refer to the perceived costs customers would have to incur in order to terminate their relations with a firm (Gruen et al. 2000) and include the searching costs for alternatives (Jones et al. 2010) and vast learning requirements. Often it is a lack of alternative service providers which leads to continuance commitment, meaning that substitutes are either scarce or unable to compete with the initial service provider (Evanschitzky, Iyer, Plassmann, Niessing and Meffert 2006). In addition, these perceived high costs result in high levels of continuance commitment which are, in turn, rooted in customers' dependence on the firm (Gundlach, Achrol and Mentzer 1995).

Normative commitment, the most recently identified commitment type, is defined as the degree to which an individual is psychologically attached to a relational partner as a result of perceived obligation (Jones et al. 2010). It has been found that normative commitment stems from socialisation processes during which customers adopt a set of subjective norms to guide the appropriateness of their actions (Bansal, Irving and Taylor 2004).

In the context of academia, Metzner and Bean (1987) argue that commitment relates to the psychological attachment that students have towards an HE institution, academic processes, as well as towards domain-specific interests. Once students have committed themselves, they are willing to assign more time, resources or energy in their pursuit of scholarly success (Sheard and Golby 2007). Therefore, Ramsey and Lorenz (2016) believe that academic commitment is an important outcome when students set goals and exert efforts to strengthen their skills. As soon as academic commitment has been established, students gain - by means of improved self- 
perception - knowledge and skills as well as the ability to confront challenging situations (Liao and Ji 2015). Furthermore, Strauss and Volkwein (2004) found that commitment is a strong predictor of students' intent to persist, whilst Cabus (2015) established a significantly positive relationship between student commitment and reduced failure rates. Student commitment should therefore be viewed from the perspective of a student's commitment towards goals, time schedules and study plans (Martinsuo and Turkulainen 2011).

\section{PHYSICAL ENVIRONMENT}

Throughout their daily schedules, individuals interact with many distinct physical environments by means of behavioural processes such as consumption, experience, utilisation or disposal (Schiffman and Kanuk 2010). These physical environments consist of multiple dimensions which are able to stimulate all individuals' senses, such as sight, hearing, smell, touch and taste. The term 'servicescape' is often used to describe the physical environment in which a service is delivered (Line, Hanks and Kim 2015), and traditionally include three reflective elements: spatial layout and functionality; ambient conditions; and signs, symbols and artefacts (Bitner 1992). However, recent research suggests that two additional components should be added to the servicescape mix, namely 'virtual servicescape' (Rafaeli and Vilnai-Yavetz 2004) and ‘social servicescape’ (Tombs and McColl-Kennedy 2003).

Designing a service environment (such as required by HE institutions) is not only an important competitive marketing tool, but an effective design can establish a desired positioning and image and alter quality perceptions (Babin, Boles and Griffin 2015). Furthermore, a servicescape design is especially applicable to interpersonal services, which are typical at HE institutions, where both the customers (students) and the employees are highly involved in the service delivery process by performing critical tasks (Bitner 1992).

Higher education institutions face the challenging task of selling an intangible offering, as their core service is directed towards people's minds (Wilson, Zeithaml, Bitner and Gremler 2016). Therefore, the use of traditional elements and ways to introduce and sell their offerings may no longer be effective. Institutions of HE thus should continuously search for new and innovative ways to communicate with their clientèle. One of these approaches is to focus on the physical environment, and, more importantly, to find a mix of physical elements that best suit the interest of all their stakeholders. However, despite the richness of research on servicescapes and physical environments, it appears that the application of the concept in an HE environment in particular is under-researched.

To address the multiple concepts that refer to physical environment elements, the concept 
'servicescape' will be used during the remainder of this study.

\section{SERVICESCAPE AND COMMITMENT}

Several studies have confirmed the effect of the physical environment on emotional responses and behavioural intentions (Lee, Chua and Han 2016; Han and Ryu 2009; Ryu and Jang 2008). Despite the substantial body of evidence that exists on the importance of servicescape and commitment as separate concepts, there appears to be a gap in the literature about the interrelatedness of these two concepts. This lack in the literature is noticed at a time when HE institutions need to understand the role that servicescape elements play when student commitment is managed. This section of the study, therefore, examines the effect of five attributes of servicescape, namely ambient conditions; spatial layout and functionality; communicators; virtual servicescape and social servicescape on student commitment.

\section{Ambient conditions}

Ambient conditions of servicescape entail sensory stimuli such as scent, noise level, temperature and lighting (Line at al. 2015). The physiological effects of atmospherics are more apparent. For example, loud noise or extreme temperatures may cause discomfort; bad odours or poor air quality may inhibit normal breathing and extreme lighting conditions may weaken sight and increase the risk of injury (Bitner 1992). According to Lin (2004), lighting in an environment can influence customers' consciousness of physical, emotional, and psychological facets in a particular environment. When lighting is designed to be in congruence with a service environment, customers are expected to experience pleasant feelings (Steffy 1990), causing them to lengthen their stay in that environment (Areni and Kim 1993). Other ambient conditions are colour (Lin 2004; Dube and Morin 2001), music and background noise (Lin 2004; Areni and Kim 1993), and odours or scents (Bone and Ellen 1999).

By demonstrating that a specific ambient stimulus of a servicescape activates a customer's sensory system and ultimately forming certain emotional, cognitive and behavioural responses towards a firm, it is posited that sensory cues may affect customer commitment. As mentioned before, customer commitment, in turn, is an attitudinal construct that comprises three components, namely affective commitment, continuance commitment and normative commitment.

Based on the literature review and the specific objectives of the study, the following hypotheses are proposed: 
$\mathrm{H}_{1 \mathrm{a}}$ There is a positive relationship between servicescape ambient conditions and affective student commitment

$\mathrm{H}_{1 \mathrm{~b}}$ There is a positive relationship between servicescape ambient conditions and continuance student commitment

$\mathrm{H}_{1 c}$ There is a positive relationship between servicescape ambient conditions and normative student commitment

\section{Spatial layout and functionality}

Environmental design cues are instrumental in assisting individuals to achieve their purchasing goals, which frequently includes convenience through the successful completion of employees' actions (Baker, Parasuraman, Grewal and Voss 2002). Spatial layout is defined as the arrangement of rooms, equipment and furnishings, along with the spatial relationships among them (Medabesh and Upadhyaya 2012). In addition to the spatial layout, functionality refers to the ways in which these items can fulfil individual needs and enhance service performance.

According to Baker et al. (2002), the layout of a servicescape, the equipment used during service delivery as well as in a general facility, and the built structure itself, substantially influence individuals' affections, while it also facilitates the formation of their cognitive judgments (Lin 2004). Furthermore, the placement of furniture and the volume of interior space, portray visible or invisible boundaries, spaciousness (Ching 1996) or confinement and ease of movement, or in other words, traffic flow (Mari and Poggesi 2013).

Both the customers’ and employees’ needs are considered during spatial layout and design to ensure that the equipment and furnishings promote optimal functioning, based on the latter's degree of interaction with the environment (Bitner 1992). Furniture serves as a link between the space and its occupants while conveying a firm's personality and influencing individuals' affective responses, particularly of comfort (Medabesh and Upadhyaya 2012). Moreover, as an example of spatial layout and design's effect on customer cognitions, offices in a service facility may induce certain beliefs about the organisation's competence, trustworthiness and dependability, based on aspects such as office layout and interior design. The following hypotheses are therefore assessed:

$\mathrm{H}_{2 a}$ There is a positive relationship between servicescape spatial layout and functionality and affective student commitment

$\mathrm{H}_{2 b}$ There is a positive relationship between servicescape spatial layout and functionality and continuance student commitment 
$\mathrm{H}_{2 c}$ There is a positive relationship between servicescape spatial layout and functionality and normative student commitment

\section{Communicators}

What initially has been classified as signs, symbols and artefacts by Bitner (1992), simply refer to those items in a servicescape serving as implicit and explicit communicators about the physical environment to its occupants (Medabesh and Udaphyaya 2012). Explicit signals are those signs and labels featuring on the exterior and interior of a service facility which fulfil the function of directing individuals and informing them of rules and policies so that they can respond or act appropriately. Signage as an explicit communicator, conveys an organisation's image which has been found to be positively related to customer loyalty (Kandampully and Suhartanto 2000).

More indirect environmental cues, serving as implicit communicators of standard expected behaviour as well as the meaning of the setting, are objects such as décor, artwork and other displayed items. Such objects transmit messages of symbolic meaning and develop an overall impression about the firm in customers' minds (Medabesh and Udaphyaya 2012). It has also been reported that signs, symbols and artefacts are positively associated with customer support of a service firm in terms of customers' external responses, such as approach behaviour, staying with the firm and repeat patronage (Bitner 1992).

It is reasonable to expect that communicators could influence commitment on various levels, based on the prior discussion suggesting that interior and exterior signals may influence an individual's decision to stay with an organisation, and whether or not they will make repeat purchases with the service provider (Bateson and Hui 1992). Based on the literature review, the following hypotheses are formulated:

$\mathrm{H}_{3 \mathrm{a}}$ There is a positive relationship between communicators and affective student commitment

$\mathrm{H}_{3 \mathrm{~b}}$ There is a positive relationship between communicators and continuance student commitment

$\mathrm{H}_{3 c}$ There is a positive relationship between communicators and normative student commitment

\section{Virtual servicescape}

Developments in technology opened new channels for both the retail and services sector 
(Browne, Durret and Wetherbe 2004), which resulted in the focus being shifted from a physical servicescape, to a virtual one as well (Mari and Poggesi 2013). A virtual servicescape, also referred to as ‘cyberscape’ (Williams and Dargel 2004), ‘e-servicescape’ (Hopkins, Grove, Raymond and La Forge 2009) or 'e-scape' (Koering 2003), can be defined as the purposeful design of web environments to generate positive effects in visitors to enhance favourable customer responses (Dailey 2004).

It has become increasingly important to comprehend the effects of e-servicescape on customers (Zafar, Verma and Baran 2003). When purchases or service encounters take place on a virtual platform, the servicescape plays a key role in representing a firm and forming customers' perceptions about the firm. These perceptions, in turn, may lead to expectations based on the firm’s virtually created image (Rafaeli and Vilnai-Yavetz 2004).

The dimensions of a virtual servicescape are primarily based on Bitner's (1992) servicescape model along with some new additional cues. Mari and Poggesi (2013) directly applied ambient cues of a traditional servicescape to e-scape, and found that colour specifically attracted considerable attention in the e-scape environment (Nitse, Parker, Krumwiede and Ottaway 2004). Griffith (2005) examined space and functionality cues and discovered that customer-friendly interfaces are preferred in a virtual servicescape layout. In addition, new stimuli (Mari and Poggesi 2013) have been identified, namely ‘design cues’ (e.g. screen clutter, simplicity of search paths, and speed of presentation), 'navigational atmosphere', and ‘timeliness of information'. Furthermore, 'site security' has proved to be a central issue for users of virtual servicescapes (Harris and Goode 2010). Based on the evidence in the literature, the following hypotheses are formulated:

$\mathrm{H}_{4 \mathrm{a}}$ There is a positive relationship between a virtual servicescape and affective student commitment

$\mathrm{H}_{4 \mathrm{~b}}$ There is a positive relationship between a virtual servicescape and continuance student commitment

$\mathrm{H}_{4 \mathrm{c}}$ There is a positive relationship between a virtual servicescape and normative student commitment

\section{Social servicescape}

Service encounters often occur in settings where multiple customers share a particular servicescape with one another (Grove and Fisk 1997). It is therefore not unexpected to learn that in recent years, a growing emphasis is placed on the social facets of the service delivery 
process. A conceptual model called the 'social servicescape' model, introduced by Tombs and McColl-Kennedy (2003), accounts for the effect of social density and the portrayed emotions of other customers on customer-affective states, subsequently resulting in cognitive and behavioural responses. The same model (Tombs and McColl-Kennedy 2003) posits that a social servicescape comprises five variables: purchase occasion (service context), social density (physical elements), displayed emotions of others, customers' affective responses (internal), and customers' cognitive responses (behavioural intent or actual behaviour).

Social density, or crowdedness, refers to a psychological state when there is less space available than what is demanded (Eroglu and Machleit 1990). This social aspect of the service environment may aid or constrain the level of pleasure experienced by customers. As a result, customers' feelings towards a firm (i.e. their affective state) determine either an approach or avoidance behaviour, such as making repeat purchases or not (Tombs and McColl-Kennedy 2003). Social interactions are deemed as consequences of interactions and exchanges among customers, employees and the environment, rather than being viewed as environmental stimuli (Bitner 1992). Along the same lines, a social servicescape acts as a facilitator of social interactions among customers themselves, as well as among customers and employees (Mari and Poggesi 2013). Therefore, a social servicescape does not merely represent physical environmental cues, but it also provides social meaning (Tombs and McColl-Kennedy 2003). Against this background, the following hypotheses are put forward:

$\mathrm{H}_{5 a}$ There is a positive relationship between social servicescape and affective student commitment

$\mathrm{H}_{5 b}$ There is a positive relationship between social servicescape and continuance student commitment

$\mathrm{H}_{5 c}$ There is a positive relationship between social servicescape and normative student commitment

The hypothesised relationships are graphically depicted in Figure 1.

\section{METHODOLOGY}

A quantitative, cross-sectional approach was used to gather data from a carefully selected target population.

Measurement instrument: A self-administered questionnaire was used to gather the data. During the questionnaire development, items from existing studies were selected to measure 
the constructs. Therefore, only items and scales of which the reliability and internal consistency were previously established, were considered for inclusion in the study. The scales to measure the dependent variable (consisting of three sub-dimensions) were predominantly taken from the following studies: Bansal et al. (2004), Garbarino and Johnson (1999) and Walter, Mueller and Helfert (2000). The five independent variables were measured using scales that emanated from Wakefield and Blodgett (1996), Lin and Mattila (2010), Raajpoot (2002), Ryu, Lee and Kim (2012), Parasuraman, Zeithaml and Malhotra (2005), Harris and Goode (2010) and Rosenbaum and Montoya (2007).

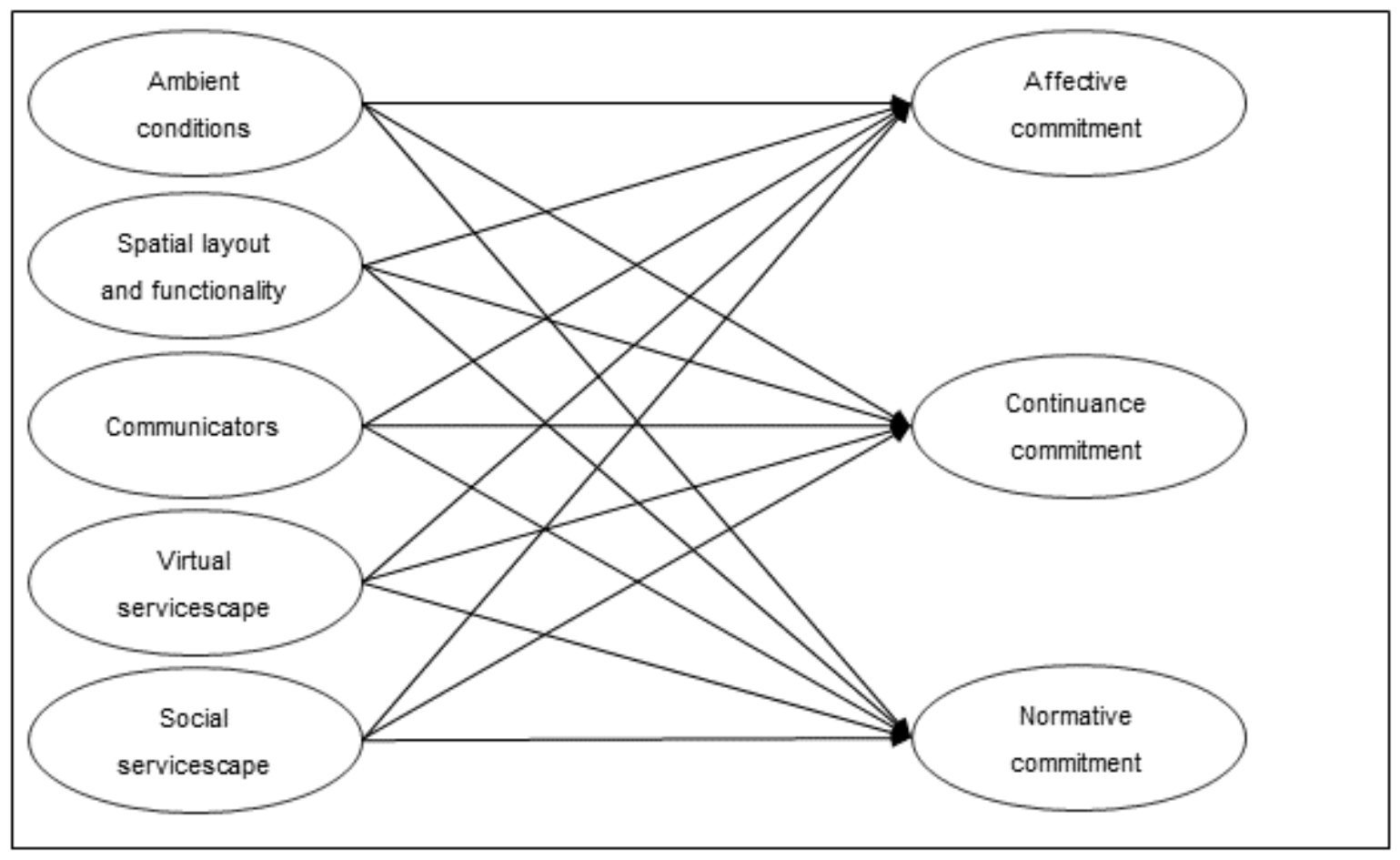

Figure 1: Hypothesised relationships

Five items were used to measure each of the dimensions of servicescape (the independent variables), whilst six items were used to assess each of the three types of commitment. The final measurement instrument therefore consisted of 43 items. All scales were measured using a seven-point Likert scale (1=strongly disagree and 7=strongly agree).

Sampling: The selected target population for this study was registered students at institutions of HE in South Africa. A non-probability sample was used to select respondents from a multicultural South African university, whilst convenience sampling was used as sampling technique. A total of 290 respondents participated in the study.

Data collection: Respondents were given a self-administered questionnaire, along with a cover letter briefly explaining the objectives of the study. An informed consent form was also 
included in which respondents had to indicate their agreement to participate.

Data analysis: The validity of the data was assessed by means of a factor analysis, whilst Cronbach alphas were used to determine the reliability of the measurement instrument. The relationships between the independent and dependent variables were assessed by means of regression analyses. The statistical program SPSS version 23 was used for all analyses.

Ethical considerations: Ethical clearance for the study was obtained from the Departmental Ethical Screening Committee, as well as the Research Ethics Committee, and overall institutional permission was received since its students were used in the research.

\section{EMPIRICAL RESULTS}

A total of 290 respondents participated in the research. Since no sample frame was available, a response rate could not be determined. A confirmatory factor analysis captured five factors related to the proposed independent variables: ambient conditions (AM), spatial layout and functionality (SPA), communicators (CO), virtual servicescape (VIR) and social servicescape (SOC). Principal Component Analysis was selected as method of extraction along with Direct Oblimin rotation based on the assumption that the data were correlated. The rotation converged in 12 iterations, and based on the KMO measure which loaded higher than 0.7 and the Bartlett's test score which was significantly lower than 0.05 , the collected data could indeed be analysed. Items which loaded below 0.4 were removed. In the final instance, a five-structure pattern as shown in Table 1, emerged:

Table 1: Factor analysis

\begin{tabular}{|c|c|c|c|c|c|}
\hline \multirow{2}{*}{ Items } & \multicolumn{5}{|c|}{ Factors } \\
\hline & 1 & 2 & 3 & 4 & 5 \\
\hline AM5 & .774 & & & & \\
\hline $\mathrm{CO} 4$ & .731 & & & & \\
\hline $\mathrm{CO} 5$ & .679 & & & & \\
\hline AM1 & .675 & & & & \\
\hline $\mathrm{CO} 3$ & .526 & & & & \\
\hline VIR4 & & .819 & & & \\
\hline VIR1 & & .787 & & & \\
\hline VIR3 & & .652 & & & \\
\hline VIR2 & & .636 & & & \\
\hline VIR5 & & .529 & & & \\
\hline SPA1 & & & -.853 & & \\
\hline SPA2 & & & -.657 & & \\
\hline SPA4 & & & -.554 & & \\
\hline SPA3 & & & -.447 & & \\
\hline SOC5 & & & & -.809 & \\
\hline SOC4 & & & & -.690 & \\
\hline SOC1 & & & & -.520 & \\
\hline SOC3 & & & & & .760 \\
\hline AM2 & & & & & -.661 \\
\hline
\end{tabular}


Based on the results depicted in Table 1, the following adjustments were made:

Factor 1: This newly formed factor consisted of two items from ambient conditions as well as three of the initial communicator items. The two-condition items refer to the interior colour schemes used in facilities, as well as the degree to which furniture is colour-coded. In turn, the three remaining communicator items all refer to the HE institution's architecture and interior décor. Therefore, it is argued that similarities between the items could exist. The label ‘communicators' was subsequently retained.

Factor 2 in Table 1 shows a stable and satisfactory output for the dimensions of virtual servicescape. None of these items had to be reassigned or deleted as they loaded together well above 0.4. The same pattern was detected in terms of Factors 3 and 4, resulting in a situation where all three the original labels ('virtual servicescape', 'spatial layout and functionality', and 'social servicescape') were retained.

The final factor that emerged from the factor analysis, consisted of two items: one from ambient conditions and one from social servicescape. Both these items relate to the atmosphere of the HE institutions and how other students affect it due to their levels of tension. Therefore, this new factor was termed 'relaxed atmosphere', which replaced ambient conditions after the output of the factor analysis reassigned and regrouped a single social servicescape item with a single ambient conditions item. Both these items relate to the atmospherics of servicescape.

Cronbach's alpha was used to assess the reliability of multi-item scales for each construct. The reliability statistics for the three dependent variables (affective, continuance and normative commitment) ranged between 0.754 and 0.846 , demonstrating sufficient evidence of reliability (Nunnally 1978). The dimension 'relaxed atmosphere' rendered a reliability score of 0.363 and had to be completely removed from the dataset. Communicators (with a reliability score of 0.792) and virtual servicescape (0.795) were also found to be reliable, whilst both spatial layout and functionality (0.659) and social servicescape (0.632) were below the level of 0.7 . However, based on the view of Peterson (1994) on acceptable levels of reliability, these two dimensions were retained in the dataset.

In order to assess the hypothesised relationships, three separate regression analyses were conducted. In the first regression analysis, the four remaining dimensions (communicators, virtual servicescape, spatial layout and functionality and social servicescape) were stated as independent variables relative to affective commitment (the dependent variable). The second regression analysis used the same set of independent variables, however, continuance commitment was stated as the dependent variable. During the final regression analysis, normative commitment was indicated as the dependent variable. The results of the three regression analyses appear in Table 3. 
Table 3: Results of the regression analyses

\begin{tabular}{|c|l|l|l|}
\hline Variables & Beta & Sig. & T-value \\
\hline Regression analysis 1: Affective commitment & \multicolumn{2}{l|}{} \\
\hline Spatial layout and functionality & .177 & .003 & 3.013 \\
\hline Communicators & .293 & .000 & 4.842 \\
\hline Virtual servicescape & .146 & .017 & 2.402 \\
\hline Social servicescape & .071 & .222 & 1.224 \\
\hline Regression analysis 2: Continuance commitment & .099 & .120 & 1.558 \\
\hline Spatial layout and functionality & .262 & .000 & 3.997 \\
\hline Communicators & .132 & .047 & 1.998 \\
\hline Virtual servicescape & -.003 & .967 & -.042 \\
\hline Social servicescape & & 1.765 \\
\hline Regression analysis 3: Normative commitment & .106 & .079 & 4.588 \\
\hline Spatial layout and functionality & .284 & .000 & 2.836 \\
\hline Communicators & .176 & .005 & 1.342 \\
\hline Virtual servicescape & .080 & .181 & \\
\hline Social servicescape & & \\
\hline
\end{tabular}

Results of the first regression analysis where the dimensions of servicescape were regressed on affective commitment, indicate that three of the four dimensions are positively related to the dependent variable. Specifically, 28.4 per cent of the variation in affective commitment $\left(\mathrm{R}^{2}=.284\right)$ can be explained by three of the four dimensions of servicescape with significant influence: spatial layout and functionality, communicators, and virtual servicescape. Spatial layout and functionality is significantly and positively related to customer affective commitment based on its $p$-value of $.003(p<.05 ; \beta=.177)$. Communicators, with a $p$-value of .000 ( $p<.05 ; \beta=.293)$, suggests a significant, positive relationship between communicators and student's affective commitment. With respect to virtual servicescape, the results of the regression analysis show that the $p$-value is below .05 ( $p=.017, p<.05, \beta=.146)$, confirming that virtual servicescape has a significant and positive influence on students' affective commitment. Support was therefore found for hypotheses $\mathrm{H}_{2 \mathrm{a}}, \mathrm{H}_{3 \mathrm{a}}$ and $\mathrm{H}_{4 a}$. The study failed to find support for a relationship between social servicescape and affective commitment.

The second regression analysis concerning students' continuance commitment, indicates that 15.9 per cent of the dependent variable can be explained by two significant independent variables: communicators and virtual servicescape. The predicted relationship between communicators and students' continuance commitment was confirmed $(p=.000, p<.05, \beta=$ .262). Then, supported by the results of the regression analysis, virtual servicescape was also found to have a significant and positive influence on students' continuance commitment ( $p=.047, p<.05, \beta=.132$ ). Two hypotheses, namely $\mathrm{H}_{3 \mathrm{~b}}$ and $\mathrm{H}_{4 \mathrm{~b}}$, were therefore supported.

The final regression analysis, which assessed the relationship between the dimensions of 
servicescape and normative student commitment, reveals that 25.2 per cent of the variance in the dependent variable can also be explained by the two aforementioned variables, namely communicators and virtual servicescape. As the independent variable, communicators were found to be positively related to students' normative commitment ( $p=.000, p<.05, \beta=.284$ ). The positive relationship between virtual servicescape and normative commitment was confirmed by the third regression analysis $(p=.005, p<0.05, \beta=.176)$. Hypotheses $\mathrm{H}_{3 c}$ and $\mathrm{H}_{4 c}$ were hereby supported.

The results of the regression analyses are graphically represented in Figure 2.

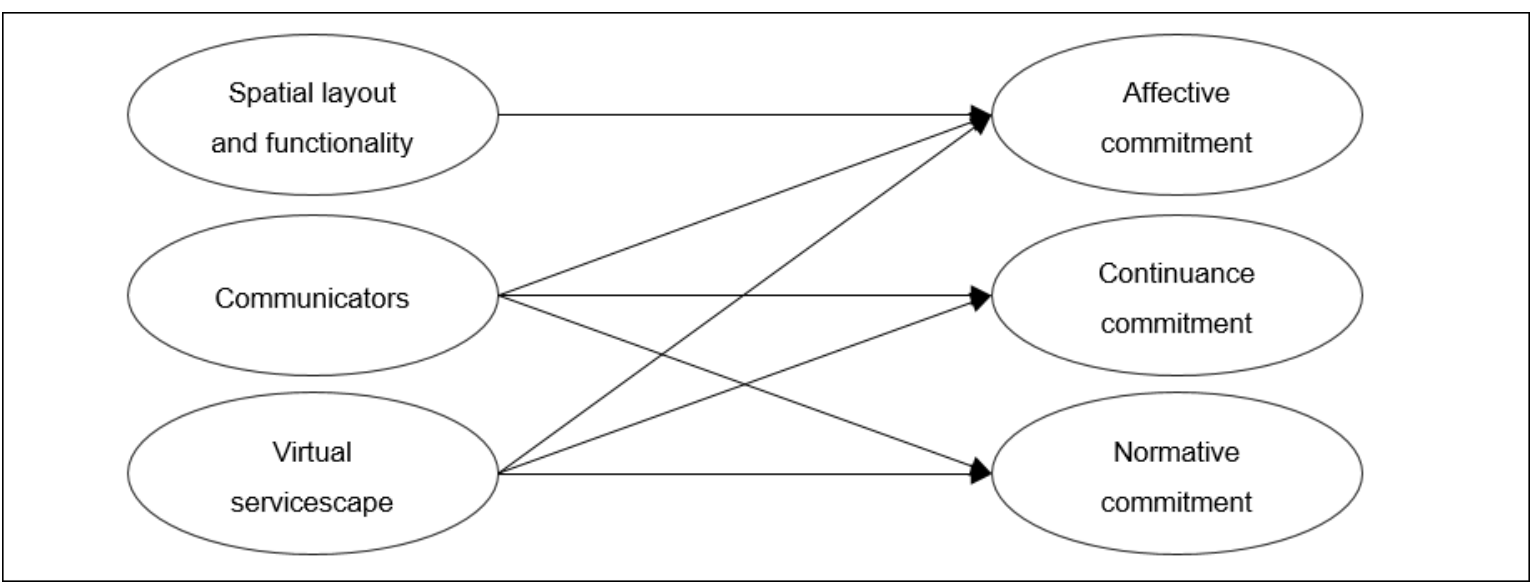

Figure 2: Hypotheses supported

\section{DISCUSSION}

The results firstly indicate that three dimensions significantly and positively influenced students’ affective commitment: spatial layout and functionality, communicators, and virtual servicescape. Secondly, the data revealed that only communicators and virtual servicescape were positively related to continuance commitment. In the context of this study, it was found that these two variables have the ability to induce this rational form of commitment amongst students at an HE institution. Thirdly, the results of the regression analyses illustrated how these two variables (communicators and virtual servicescape) influence normative commitment. In other words, the relevant physical and virtual aspects of these variables will lead to students feeling as though they have the moral obligation to stay with a particular service provider.

Apart from these three main contributions, some additional findings deserve attention. Firstly, as a relatively new dimension of servicescape, social servicescape did not significantly influence any type of student commitment towards an HE institution. Thus, it may be inferred that students' overall commitment towards an HE institution will not be significantly influenced by what constitutes social servicescape. Secondly, communicators was found to be the strongest 
predictor of all three types of student commitment, followed by virtual servicescape, which was only surpassed by spatial layout and functionality in its relationship with affective commitment.

The study appears to be consistent with some areas of the existing literature. For example, the importance of spatial layout and functionality (Kerin, Varadarajan and Peterson 1992), communicators (Bateson and Hui 1992) and virtual servicescape (Menon and Kahn 2002) was reaffirmed. However, the fact that the results of this study failed to support certain dimensions of servicescape, might be somewhat unexpected. For example, in their study, Medabesh and Udaphyaya (2012) found that individuals' overall assessment of a service facility's spatial layout and functionality influenced their rational attitudes towards and support of a service provider (therefore resulting in continuance commitment). This finding could not be confirmed in the present study. It could therefore be assumed that the spatial layout and functionality of HE institutions does not influence students' perceptions of the servicescape as a restraint prohibiting them from switching to alternative institutions.

Also, despite Namasivayam and Lin's (2008) finding that the design and functionality of a servicescape can be manipulated to such an extent that it may enhance customer satisfaction and repurchase behaviour, this study failed to provide evidence for the relationship between spatial layout and functionality and normative commitment.

The non-support for all three the hypotheses pertaining to social servicescape, deserves closer inspection. This non-support is in contrast with the findings by Tombs and McCollKennedy (2003). A reasonable explanation for the non-support of these hypotheses may lie in the diversity of South Africa which may make it more difficult for students to feel as though they belong, resemble or are able to identify or share values with the majority of their fellow students and, consequently, develop positive attitudinal loyalty towards an HE institution. It is also plausible that students studying at South African HE institutions may follow a more rational approach when making decisions about commitment, as opposed to opting for an emotional decision-making route.

South Africans are different in terms of their wealth distribution, as well as their cultural and contextual backgrounds. Therefore, it is debatable whether South African students would rather evaluate their service experiences clinically without viewing social servicescape as a contributing factor or determinant of their commitment towards an HE institution.

\section{MANAGERIAL IMPLICATIONS}

Higher education institutions in South Africa face the daunting task of creating infrastructure to meet the escalating demand for higher education. In an effort to meet the demand as 
efficiently as possible, the focus should also be placed on the re-development of facilities. Spatial layout and functionality becomes more important than ever, since this study has proved that a student's commitment to an institution of HE is dependent on the quality of the physical learning environment. Consultation with industrial psychologists thus becomes imperative.

The critical role of communicators cannot be overemphasised, especially since this concept influences student commitment in a holistic manner; neither continuance or affective student commitment, nor normative student commitment can be managed without an extensive focus on communicators. Therefore, the attractiveness of the architecture, interior décor, interior colour schemes and how these environmental cues tie in with the public image of $\mathrm{HE}$ institutions are critically important. Higher education institutions’ possible negligence to maintain the aforementioned physical cues may portray a 'do-not-care' message, whilst these elements are important attributes of student commitment. From a branding perspective, HE institutions should realise the value of signage in terms of style, fonts and size elements. On a practical level, a number of aspects become almost non-negotiable, such as clear signage (both inside and outside facilities), fire-extinguishers, clearly visible venue numbers, directions towards restrooms and disabled facilities, as well as outdoor maps and/or directions.

In terms of virtual servicescape, electronic tools of communication are integral to students' commitment to an HE institution. For example, an institution's website has become an essential platform that is accessed almost daily for the purposes of communication, administration, information and research. A virtual servicescape should continuously be updated, with specific focus on aspects such as ease-of-use, visually appealing graphics and images, innovative design, well-organised information, and high speed. A relative simple action such as regularly servicing printing devices in computer facilities, could have a lasting effect on a student's commitment towards an institution of HE.

Although institutions of HE might view the proper management of physical elements as a daunting challenge, the opposite is true: It is often easier and less time-consuming to attain student commitment by means of servicescape than to focus on less tangible concepts, such as managing student learning. Furthermore, servicescape can be modified in the relative short run, whilst influencing student commitment by means of the actual educational part of the service offering, requires a much more long-term approach. HE institutions in South Africa should realise that managing student commitment calls for a holistic approach, and that it is not dependent on teaching only. Besides, it is almost certain that influencing student commitment by focusing on the actual educational part of the service offering (as opposed to focusing on physical elements), will be an even more challenging task. 


\section{LIMITATIONS AND FUTURE RESEARCH}

This study was conducted among students of one HE institution only, and the results of the study may thus not necessarily be generalised to all South African HE institutions. However, since the HE institution in this study can be classified as a large, culturally diverse institution, the results can at least be generalised to a number of similar South African institutions.

Although not a limitation to the study as such, the relative unavailability of literature on the term 'social servicescape' restricted its conceptualisation. Moreover, the inadequate literature on the determinants and effects of social servicescape resulted in a lack of external validity.

Interesting findings could emanate from research on the influence of demographics (such as gender) on students' commitment to an HE institution. Also, a further step could be to examine experimentally the behavioural implications of each of the dimensions of servicescape. An example of this would be to establish the effect of communicators and virtual servicescape on other relational constructs as these two dimensions were identified as the most significant contributors to student commitment in this study. The result of such a study could help practitioners to gain a deeper understanding of other relational effects associated with the various dimensions of servicescape, especially the effects on loyalty as the latter is widely acknowledged to translate into long-term profitability.

More importantly, there is a need for additional studies to examine social servicescape in more depth while paying special attention to its conceptualisation, antecedents and effects. These areas are relatively under-researched and consequently provide ample opportunities for those marketing scholars who are interested to contribute to this field of research.

\section{CONCLUSION}

Although marketing has traditionally been associated with business activities, the domain of marketing has expanded considerably during the past two decades. Marketing has now emerged as a multi-dimensional field of study, and its influence stretches far beyond than was initially conceived. It is therefore not unexpected to find that a variety of industries, such as higher education, is increasingly turning to marketing principles to achieve their educational objectives.

This study provides an empirical perspective to the potential use of physical evidence when student commitment is managed. The findings of the study support the notion that an institution of HE's servicescape contribute significantly to the commitment of its students. 
Furthermore, the study found that it is important for HE institutions to not approach student commitment as a unidimensional construct, as specific relationships (relating to the three distinct components of commitment) have been confirmed. Each of these components, therefore, needs to be managed separately. For example, a more comprehensive approach should be used to manage affective commitment, whilst both continuance and normative commitment could primarily be established by using servicescape communicators. It is often the smaller changes (such as changing signage) that render the biggest return.

The ever-changing HE environment in South Africa necessitates stakeholders to reconsider the way in which they manage their resources, of which students are considered to be the most critical resource. Once students commit themselves towards their selected institution of HE, it could have a significant effect on student success.

\section{REFERENCES}

Areni, C. S. and R. Kim. 1993. The influence of in-store lighting on consumers' examination of merchandise in a wine store. International Journal of Research in Marketing 11(2): 117-125.

Babin, B. J., J. S. Boles and M. Griffin. 2015. The moderating role of service environment on the customer share $\rightarrow$ customer commitment relationship. In New meanings for marketing in a new millennium, 266-271. Springer International Publishing.

Baker, J., A. Parasuraman, D. Grewal and G. B. Voss. 2002. The influence of multiple store environment cues on perceived merchandise value and patronage intentions. Journal of Marketing 66(2): 120 141.

Bansal, H. S., P. G. Irving and S. F. Taylor. 2004. A three-component model of customer commitment to service providers. Journal of the Academy of Marketing Science 32(3): 234-250.

Bateson, J. E. G. and M. K. Hui. 1992. The ecological validity of photographic slides and videotapes in simulating the service setting. Journal of Consumer Research 19(2): 271-281.

Beck, H. P. and M. Milligan. 2014. Factors influencing the institutional commitment of online students. The Internet and Higher Education 20: 51-56.

Biscaia, R., A. Correia, A. F. Rosado, S. Ross and J. Maroco. 2013. Sport sponsorship: The relationship between team loyalty, sponsorship awareness, attitude toward the sponsor, and purchase intentions. Journal of Sport Management 27(4): 288-302.

Bitner, M. J. 1992. Servicescapes: The impact of physical surroundings on customers and employees. Journal of Marketing 56(2): 57-71.

Bone, P. F. and P. S. Ellen. 1999. Scents in the marketplace: Explaining a fraction of olfaction. Journal of Retailing 75(2): 243-262.

Browne, G. J., J. R. Durret and J. C. Wetherbe. 2004. Consumer reactions towards clicks and bricks: Investigating buying behaviour on-line and at store. Behaviour \& Information Technology 23(4): 237-245.

Cabus, S. J. 2015. Does enhanced student commitment reduce school dropout? Evidence from two major dropout regions in the Netherlands. Regional Studies 49(4): 599-614.

Ching, F. 1996. Architecture: Form, space, and order. New York: Van Nostrand.

Dachner, A. M. and B. M. Saxton. 2015. If you don't care, then why should I? The influence of instructor commitment on student satisfaction and commitment. Journal of Management Education 39(5): 549-571. 
Dailey, L. 2004. Navigational web atmospherics: Explaining the influence of restrictive navigation cues. Journal of Business Research 57(7): 795-803.

Dube, L. and S. Morin. 2001. Background music pleasure and store evaluation intensity effects and psychological mechanisms. Journal of Business Research 54(2): 107-113.

Eroglu, S. and K. A. Machleit. 1990. An empirical examination of retail crowding: Antecedents and consequences. Journal of Retailing 66(2): 201-221.

Evanschitzky, H., G. R. Iyer, H. Plassmann, J. Niessing and H. Meffert. 2006. The relative strength of affective commitment in securing loyalty in service relationships. Journal of Business Research 59(12): 1207-1213.

Fullerton, G. 2003. When does commitment lead to loyalty? Journal of Service Research 5(4): 333344.

Garbarino, E. and M. S. Johnson. 1999. The different roles of satisfaction, trust, and commitment in customer relationships. Journal of Marketing 63(2): 70-87.

Gilliland, D. I. and D. C. Bello. 2002. Two sides to attitudinal commitment: The effects of calculative and loyalty commitment on enforcement mechanisms in distribution channels. Journal of the Academy of Marketing Science 30(1): 24-43.

Griffith, D. A. 2005. An examination of the influences of store layout in online retailing. Journal of Business Research 58(10): 1391-1396.

Grove, S. J. and R. P. Fisk. 1997. The impact of other customers on service experiences: A critical incident examination of 'getting along'. Journal of Retailing 72(1): 63-85.

Gruen, T. W., J. O. Summers and F. Acito. 2000. Relationship marketing activities, commitment, and membership behaviors in professional associations. Journal of Marketing 64(3): 34-49.

Gundlach, G. T., R. S. Achrol and J. T. Mentzer. 1995. The structure of commitment in exchange. Journal of Marketing 59(1): 78-93.

Han, H. and K. Ryu. 2009. The roles of the physical environment, price perception, and customer satisfaction in determining customer loyalty in the restaurant industry. Journal of Hospitality \& Tourism Research 33(4): 487-510.

Harris, L. C. and M. M. H. Goode. 2010. Online servicescapes, trust, and purchase intentions. Journal of Services Marketing 24(3): 230-243.

Hopkins, C. D., S. J. Grove, M. A. Raymond and M. C. La Forge. 2009. Designing the e-servicescape: Implications for online retailers. Journal of Internet Commerce 8(1-2): 23-43.

Jones, T., G. L. Fox, S. F. Taylor and L. R. Fabrigar. 2010. Service customer commitment and response. Journal of Services Marketing 24(1): 16-28.

Kandampully, J. D. and D. Suhartanto. 2000. Customer loyalty in the hotel industry: The role of customer satisfaction and image. International Journal of Contemporary Hospitality Management 12(6): 346-351.

Kelmer, G., G. K. Rhoades, S. Stanley and H. J. Markman. 2013. Relationship quality, commitment, and stability in long distance relationships. Family Process 52(2): 257-270.

Kerin, R. A., P. R. Varadarajan and R. A. Peterson. 1992. First-mover advantage: A synthesis, conceptual framework, and research propositions. Journal of Marketing 56(4): 33-52.

Koering, S. K. 2003. E-scapes: The electronic physical environment and service tangibility. Psychology \& Marketing 20(2): 151-167.

Lee, S., B. L. Chua and H. Han. 2016. Role of service encounter and physical environment performances, novelty, satisfaction, and affective commitment in generating cruise passenger loyalty. Asia Pacific Journal of Tourism Research 20(10): 1-16.

Liao, C. and C. Ji. 2015. The origin of major choice, academic commitment, and career-decision readiness among Taiwanese college students. Career Development Quarterly 63(2): 156-170.

Lin, I. Y. and A. S. Mattila. 2010. Restaurant servicescape, service encounter, and perceived congruency 
on customers' emotions and satisfaction. Journal of Hospitality Marketing \& Management 19(8): 819-841.

Lin, I. Y. 2004. Evaluating a servicescape: The effect of cognition and emotion. Hospitality Management 23(2): 163-178.

Line, N. D., L. Hanks and W. G. Kim. 2015. An expanded servicescape framework as the driver of place attachment and word of mouth. Journal of Hospitality \& Tourism Research 20(10): 1-24.

Mari, M. and S. Poggesi. 2013. Servicescape cues and customer behavior: A systematic literature review and research agenda. The Service Industries Journal 33(2): 171-199.

Martinsuo, M. and V. Turkulainen. 2011. Personal commitment, support and progress in doctoral studies. Studies in Higher Education 36(1): 103-120.

Medabesh, A. and M. Upadhyaya. 2012. Servicescape and customer substantiation of star hotels in India's metropolitan city of Delhi. Journal of Marketing \& Communication 8(2): 39-47.

Menon, S. and B. Kahn. 2002. Cross-category effects of induced arousal and pleasure on the Internet shopping experience. Journal of Retailing 78(1): 31-40.

Metzner, B. S. and J. P. Bean. 1987. The estimation of a conceptual model of non-traditional undergraduate student attrition. Research in Higher Education 27(1): 15-38.

Meyer, J. P. and N. J. Allen. 1997. Commitment in the workplace: Theory, research and application. California: Sage Publications Inc.

Meyer, J. P. and L. Herscovitch. 2001. Commitment in the workplace: Toward a general model. Human Resource Management Review 11(3): 299-326.

Morgan, R. M. and S. D. Hunt. 1994. The commitment-trust theory of relationship marketing. Journal of Marketing 58(3): 20-38.

Namasivayam, K. and I. Y. Lin. 2008. The servicescape. In Handbook of Hospitality Operations and IT, ed. P. Jones, 43-62. Oxford: Butterworth-Heinemann.

Nitse, P. S., K. R. Parker, D. Krumwiede and T. Ottaway. 2004. The impact of color in the e-commerce marketing of fashions: An exploratory study. European Journal of Marketing 38(7): 898-915.

Nunnally, J. C. 1978. Psychometric theory, New York: McGraw-Hill.

Parasuraman, A., V. A. Zeithaml and A. Malhotra 2005. ES-QUAL a multiple-item scale for assessing electronic service quality. Journal of Service Research 7(3): 213-233.

Peterson, R. A. 1994. A meta-analysis of Cronbach's coefficient alpha. Journal of Consumer Research 21(2): 381-391.

Pritchard, M., M. Havitz and D. Howard. 1999. Analyzing the commitment-loyalty link in service relationships. Journal of the Academy of Marketing Science 27(3): 333-348.

Raajpoot, N. A. 2002. TANGSERV: A multiple item scale for measuring tangible quality in foodservice industry. Journal of Foodservice Business Research 5(2): 109-127.

Rafaeli, A. and I. Vilnai-Yavetz. 2004. Emotion as a connection of physical artefacts and organizations. Organization Science 15(6): 671-686.

Ramsey, J. R. and M. P. Lorenz. 2016. Exploring the impact of cross-cultural management education on cultural intelligence, student satisfaction, and commitment. Academy of Management Learning \& Education 15(1): 79-99.

Rosenbaum, M. S. and D. Y. Montoya. 2007. Am I welcome here? Exploring how ethnic consumers assess their place identity. Journal of Business Research 60(3): 206-214.

Ryu, K. and S. C. Jang. 2008. Influence of restaurant's physical environments on emotion and behavioral intention. The Service Industries Journal 28(8): 1151-1165.

Ryu, K., H. R. Lee and W. G. Kim. 2012. The influence of the quality of the physical environment, food, and service on restaurant image, customer perceived value, customer satisfaction, and behavioral intentions. International Journal of Contemporary Hospitality Management 24(2): 200-223. 
Sheard, M. and J. Golby. 2007. Hardiness and undergraduate academic study: The moderating role of commitment. Personality and Individual Differences 43(3): 579-588.

Schiffman, L. and L. Kanuk. 2010. Global and Southern African perspectives: Consumer behaviour. Cape Town: Pearson Education South Africa.

Steffy, G. 1990. Architectural lighting design. New York: Van Nostrand Reinhold.

Strauss, L. C. and J. F. Volkwein. 2004. Predictors of student commitment at two-year and four-year institutions. Journal of Higher Education 75(2): 203-227.

Subotzky, G. 2015. Enhancing retention and success in South Africa. International Higher Education 58(March 25): 24-26.

Tombs, A. and J. R. McColl-Kennedy. 2003. Social-servicescape conceptual model. Marketing Theory 3(4): 447-475.

Vecina, M. L., F. Chacón, D. Marzana and E. Marta. 2013. Volunteer engagement and organizational commitment in nonprofit organizations: What makes volunteers remain within organizations and feel happy? Journal of Community Psychology 41(3): 291-302.

Wakefield, K. L. and J. G. Blodgett. 1996. The effect of the servicescape on customers' behavioral intentions in leisure service settings. Journal of Services Marketing 10(6): 45-61.

Walter, A., T. A. Mueller and G. Helfert. 2000. The impact of satisfaction, trust, and relationship value on commitment: Theoretical considerations and empirical results. In IMP Conference Proceedings, 1-18. Germany: University of Karlsruhe.

Williams, R. and M. Dargel. 2004. From servicescape to 'cyberscape'. Marketing Intelligence \& Planning 22(3): 310-320.

Wilson, A., V. A. Zeithaml, M. Bitner and D. D. Gremler. 2016. Services marketing: Integrating customer focus across the firm. London: McGraw-Hill Education.

Zafar, I., R. Verma and R. Baran. 2003. Understanding consumer choices and preferences in transactionbased e-services. Journal of Service Research 6(1): 51-65. 